https://doi.org/10.46813/2021-136-093

\title{
THE INFLUENCE OF CATHODE MATERIAL ON THE CHARACTERISTICS OF PULSED NEGATIVE CORONA IN OXYGEN
}

\author{
V.I. Golota, B.B. Kadolin, G.V. Taran, I.A. Pashchenko \\ National Science Center "Kharkov Institute of Physics and Technology”, Kharkiv, Ukraine \\ E-mail: kodolin@kipt.kharkov.ua
}

Change in time for the shape of the discharge current pulses of the pulsed negative corona in oxygen with copper and stainless steel cathodes has been studied for two discharge modes. The change lies in the decrease of the pulse amplitude and duration at half maximum. It is shown that for stainless steel cathodes, the amount of electric charge transferred in one pulse of the discharge current is $15 \%$ greater than for copper cathodes. It is also shown that under the maximum load mode, the amount of charge transferred in one pulse of the discharge current is decreased with time by $10 \%$ for both types of cathodes. It is shown that ozone synthesis in the electrode system with copper cathodes is $25 \%$ more efficient.

PACS: $52.80 . \mathrm{Hc}$

\section{INTRODUCTION}

Barrierless gas discharges of atmospheric pressure in oxygen-containing gases with highly inhomogeneous distribution of electric field are effective ozone sources. The issue of increasing the energy efficiency of ozone synthesis in this type of gas discharge is urgent, especially ozone production with high concentration. Ozone generators on its basis are widely used for tire recycling $[1,2]$, wastewater treatment [3], etc. Research on this type of gas discharge is aimed at determining the conditions under which it is possible to increase the energy put by the discharge per unit volume of gas while maintaining the volumetric discharge, and increasing the efficiency of ozone synthesis. This issue is solved by selecting the parameters of the discharge gap geometry, parameters of the electric pulsed power supply and gasdynamic conditions. Among the gas-dynamic conditions, only the temperature, pressure and rate of gas pumping along the discharge gap are the tools which can have the influence on the discharge characteristics. However, they provide little information on the gasdynamic conditions directly in the ionization region of the discharge, which is key both for the discharge and plasma-chemical reactions.

In [4], experimentally, on the basis of the analysis on the radiation spectrum of the discharge active zone, the gas temperature at the corona-forming tip was determined, which was $\sim 600 \mathrm{~K}$. Due to this temperature value, ozone destruction process is enhanced and ozone cannot be obtained with high efficiency. Therefore, in this paper, an attempt has been made to study the possibility of controlling the thermodynamic conditions in the immediate vicinity of the corona-forming electrode surface by enhancing the heat removal through the corona-forming cathode surface. For this, the cathodes made of the material with high thermal conductivity (copper) were used. Traditionally, the stainless steel cathodes were used in ozone generators due to their high corrosion resistance. However, stainless steel $(\mathrm{s} / \mathrm{s})$ has a thermal conductivity coefficient of $\sim 20 \mathrm{~W} /\left(\mathrm{m} \cdot{ }^{\circ} \mathrm{C}\right)$, which can lead to excessive heating of the cathode surface. The equilibrium temperature of the cathode surface corresponds to the conditions under which the heat flux from the discharge to the cathode surface is equal to the heat flux along the cathode. If the cathodes made of the material with high thermal conductivity are used, the cathode surface temperature can be significantly reduced. This will change the discharge mode. Also, both the electrodynamic parameters of the negative pulsed corona and the rate of plasma chemical synthesis will be affected.

To achieve the goal of the work, a multicathode electrode system with high-voltage pulsed power supply was chosen. The discharge was ignited in a working gas with the increased oxygen concentration up to $\sim 94 \%$. The cathodes for the electrode system were made of copper (thermal conductivity coefficient of $\left.390 \mathrm{~W} / \mathrm{m} /{ }^{\circ} \mathrm{C}\right)$ and stainless steel $12 \mathrm{X} 18 \mathrm{H} 10 \mathrm{~T}$ (S32109) (thermal conductivity coefficient of $15 \mathrm{~W} / \mathrm{m} /{ }^{\circ} \mathrm{C}$ ). Thus, comparing the discharge characteristics of these two electrode systems, it will be possible to draw a conclusion on the significance of heat removal from the discharge active zone and the efficiency of ozone synthesis.

\section{EXPERIMENTAL STAND}

The experimental stand (Fig. 2) includes the unit of plasma-chemical reactors (PCRs), oxygen source, pulsed power supply unit and measuring unit.

The experiments were carried out on the unit consisting of two separate PCRs connected in series along the working gas flow. The plasma-chemical reactor is a hollow cylinder made of finely dispersed graphite $500 \mathrm{~mm}$ long and $38 \mathrm{~mm}$ in inner diameter, which serves as an anode. The cathode is coaxially located inside the cylinder, which is a rod with the diameter of $8 \mathrm{~mm}$, on which 60 flat star-like cathode sections (Fig. 1) are fixed. The distance between the cathode sections is $6 \mathrm{~mm}$. Each cathode section has 15 separate cathodes, each $5 \mathrm{~mm}$ long and $0.5 \mathrm{~mm}$ wide.

The distance from the cathode section center to the cathode end surface was $14.5 \mathrm{~mm}$. The discharge gap was $4.5 \mathrm{~mm}$, respectively. The deviation of the discharge gap value from the specified one is less than $20 \mu \mathrm{m}$ for each cathode. The PCR electrical capacitance was $57 \mathrm{pF}$ for the PCR with a copper cathode and $54 \mathrm{pF}$ for the PCR with a stainless steel cathode. 


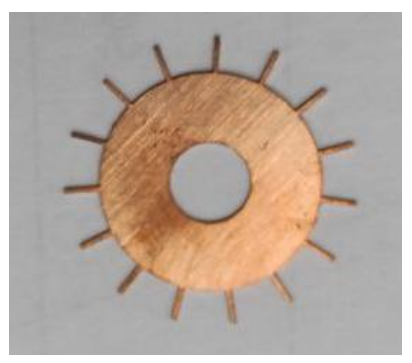

Fig. 1. Cathode section

The oxygen source includes an oxygen concentrator AirSep-D with the productivity of $1.2 \mathrm{~m}^{3} / \mathrm{h}$ for a gas mixture that contains $92 . .95 \%$ of oxygen, up to $8 \%$ of nitrogen, water vapor and argon. The water vapor content corresponds to a dew point of $-90^{\circ} \mathrm{C}$. For the normal operation of the oxygen concentrator, two oil-free air compressors AtlasCopco LF7 FF and AtlasCopco LF7 with the productivity of $0.66 \mathrm{~m}^{3} / \mathrm{min}$ each and working pressure of up to $120 \mathrm{psig}$ were used. The AtlasCopco LF7 FF air compressor is additionally equipped with a refrigerated air dryer with a dew point of $+3^{\circ} \mathrm{C}$. Gas from the oxygen concentrator is accumulated in two receivers with the capacity of 300 liters each, which are connected in series. To control the oxygen consumption, a rotameter RM $0.12 \mathrm{G}$ with the measurement range from $0.001 \mathrm{~m}^{3} / \mathrm{h}$ to $0.12 \mathrm{~m}^{3} / \mathrm{h}$ was used. The oxygen concentrtion in thegas mixture was measured with an M\&C $\mathrm{O}_{2}$-Analyzer PMA-10 paramagnetic oxygen analyzer. Oozone concentratiion in the gas mixture was measured using a Teledyne Instruments Ozone Monitor $465 \mathrm{H}$. An ozone destructor was installed at the outlet of the gas path.

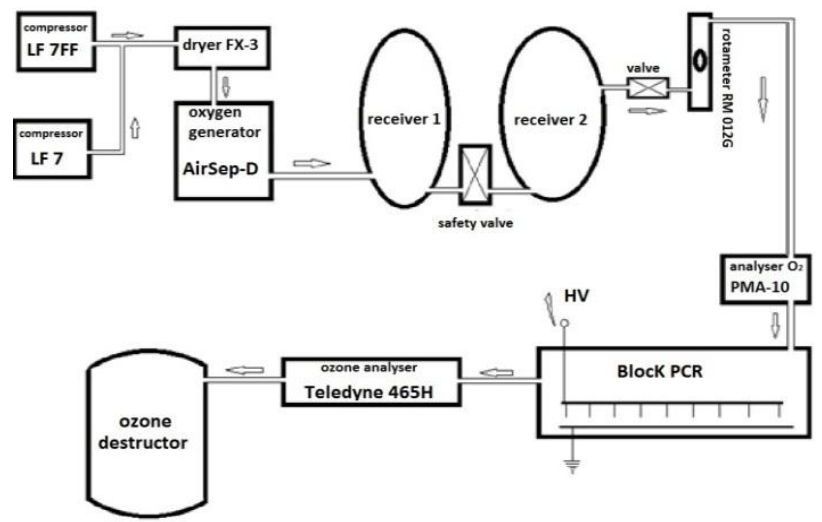

Fig. 2. Block diagram of the experimental stand

The electrical part of the experimental stand includes an HV pulsed power supply, PCR unit and measuring instruments. The HV pulsed power supply can operate under the combined power supply mode: high-voltage pulses against bias voltage. The value for the background level of the bias voltage is set by the ratio of intrinsic electric capacity for the PCR C4 unit in Fig. 4, and the capacitance of the capacitors for the bias voltage circuit $\mathrm{C} 2$ in Fig. 4. The maximum level of bias voltage is up to $3 \mathrm{kV}$. The HV pulsed power supply is designed on the basis of HV pulse transformer and has the following parameters: the pulse shape is sinusoidal, pulse repetition rate is from $200 \mathrm{~Hz}$ to $20 \mathrm{kHz}$, amplitude of $\mathrm{HV}$ pulses is from 7 to $12 \mathrm{kV}$, pulse width at half-height is $1 \mu \mathrm{s}$. It is possible to smoothly adjust the amplitude of $\mathrm{HV}$ pulse and repetition rate.

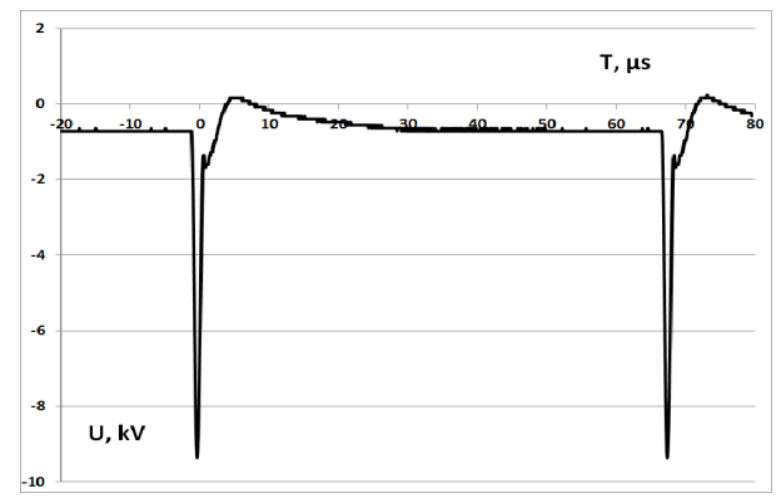

Fig. 3. Oscillogram of HV pulses

The HV pulsed power supply (Fig. 3) parameters for the PCR unit were measured using a Tektronix P6015A capacitive HV probe, which has the division ratio of $1: 1000$, resistance of $100 \mathrm{M} \Omega$, electric capacitance of $3 \mathrm{pF}, 20 \mathrm{kV} \mathrm{DC}, 40 \mathrm{kV}$ pk $100 \mathrm{~ms}$, bandwidth of $90 \mathrm{MHz}$. The HV probe is connected to a Tektronix TDS 2024B four-channel oscilloscope with the bandwidth of $200 \mathrm{MHz}$. The electric current of the PCR unit was measured using a Tektronix CT-1 current probe with the transformation ratio of $5 \mathrm{mV} / 1 \mathrm{~mA}$ and bandwidth of $1 \mathrm{GHz}$.

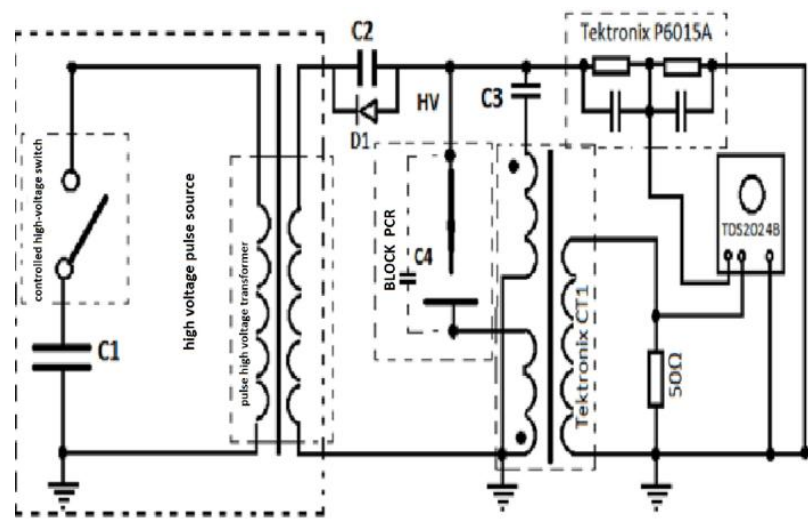

Fig. 4. Schematic diagram of the experimental stand.

$\mathrm{Cl}$ is the charging capacitor, $\mathrm{C} 2$ is the bias voltage capacitor, C3 is the capacitor that simulates the electric capacity of the PCR unit, $C 4$ is the intrinsic capacitance of the PCR unit

A compensating circuit is used to measure the discharge current. Since the electric power supply is of pulsed nature, the current flowing through the circuit of the PCR unit is the sum of gas discharge current and charging current of the PCR intrinsic capacitance, the so-called capacitive current, which has nothing to do with the gas discharge current. To separate the gasdischarge current from the total current, an additional electrical circuit was used, which includes a highvoltage capacitor connected to the electrical power circuit in parallel to the PCR unit. The value for the electric capacitance of the capacitor must be exactly equal to the electric capacitance of the PCR unit. Oscillographic recording of the current flowing through the discharge gap and the current flowing in the circuit of this capacitor is carried out simultaneously. In order to separate exactly the discharge current, it is necessary to subtract the current flowing in the capacitor circuit from the total current flowing through the PCR unit. The current is measured using a Tektronix CT 1 current 
probe, which is a measuring transformer. The primary winding of this transformer is a conductor through which electric current flows. Therefore, in case when the conductor, through which the total current of the PCR unit flows, and the conductor with the secondary capacitor current play the role of primary windings, which are switched in the opposite way, the subtraction of the secondary capacitor current from the total current of the PCR unit is carried out in a circuit, directly in the measurement process. The obtained result is a gas discharge current. In Fig. 5, an example for one of the obtained oscillograms is presented. The shape of the HV voltage pulse is shown with the upper black curve. The shape of the discharge current pulse is shown with the lower red curve.

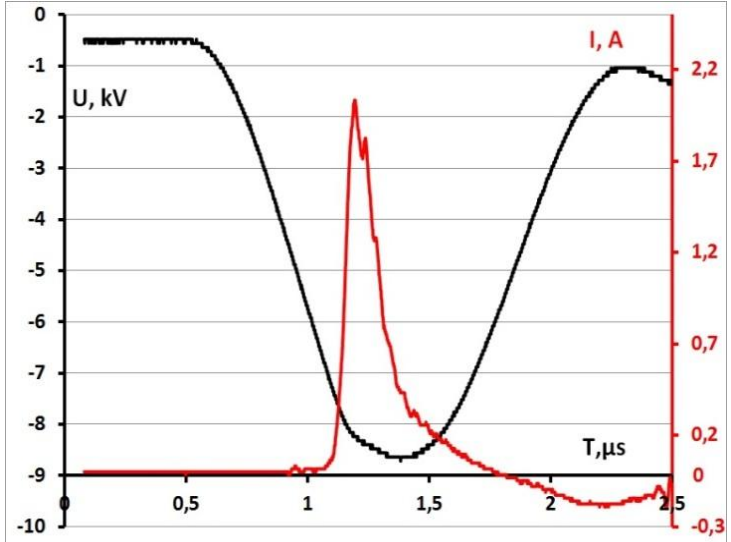

Fig. 5. Example of the oscillogram for HV pulse and discharge current

\section{EXPERIMENTAL RESULTS}

In the course of the experiments, the temporal dynamics of both the concentration of ozone produced by the PCR unit and the change in the shape of the discharge current pulses for the PCR were studied with the fixed parameters of the HV pulsed power supply for two electrode systems: with copper and stainless steel cathodes.

All the studies were carried out at the HV pulse repetition rate of $15 \mathrm{kHz}$ and fixed value of the bias power supply voltage. The PCR operating mode with a partial load, HV pulse energy of about $7.5 \mathrm{~mJ}$ with a maximum load and pulse energy of $9.5 \mathrm{~mJ}$ were studied. The maximum load corresponds to the operating mode of the PCR unit, when the transition of the pulsed corona to the spark discharge is completely excluded. The intrinsic electric capacitance of the PCR unit with copper cathodes was $114.5 \mathrm{pF}$, with stainless steel cathodes $-107 \mathrm{pF}$. The oxygen consumption was $60 \mathrm{~L} / \mathrm{min}$, oxygen purity was $94 \%$.

In Figs. 6-9, the oscillograms of the discharge current pulses for the PCR unit with stainless steel and copper cathodes are shown depending on the duration of operation. Oscillograms are synchronized with a highvoltage pulse. In all the figures, it is shown that the shape of current pulses is changed over time. The current pulse itself is shifted to the right in time with respect to HV pulse. At the partial load, for both stainless steel and copper cathodes, the current pulse becomes longer at half height. The amplitude of the current pulse for copper cathodes is not changed, and for stainless steel cathodes, it is slightly decreased. At the maximum load, the amplitude of the current pulse is decreased, and the pulse width at half height is increased. In general, the nature of changes in the shape of current pulses at the partial and maximum loads are identical, but at the maximum load, they are much stronger. It is suggested that these changes are caused by cathode heating.

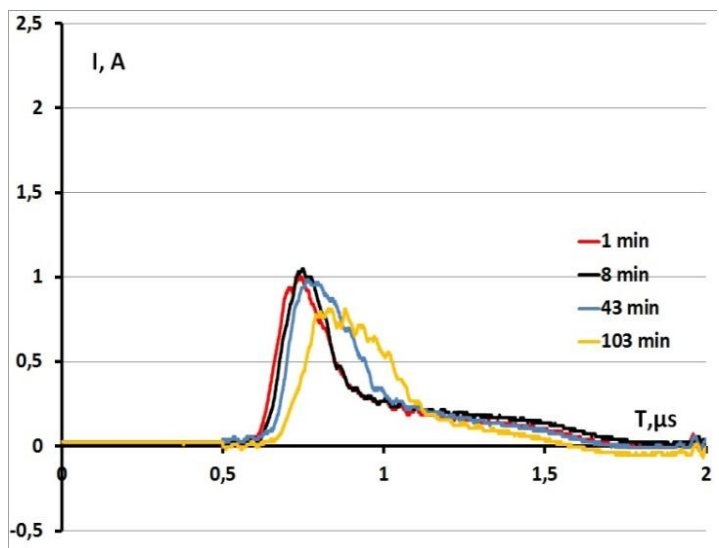

Fig. 6. Oscillograms of discharge current pulses, PCR with stainless steel cathodes at the partial load and $H V$ pulse energy of $7.55 \mathrm{~mJ}$ recorded at different duration of operation

PCR is a multi-cathode electrode system, and the PCR current pulse is the sum of current pulses for each individual cathode. Since the gas temperature is increased as it passes along the electrode system, the temperature of the cathodes located closer to the gas inlet of the PCR unit is lower than of those located closer to the outlet. Therefore, the discharge at the cathodes located at different distances from the gas inlet of the PCR unit occurs at different times as the voltage is increased at the leading edge of the voltage pulse. This explains the increase in the current pulse duration and, in part, the decrease in its amplitude.

In more heated gas, the current pulse amplitude of the individual cathode is greater at the same voltage. This compensates the decrease in the amplitude for the total current pulse of the PCR unit due to its expansion. For copper cathodes at the partial load, the amplitude of the current pulse did not change at all. To estimate the value of the total pulse current, on the basis of the obtained oscillograms, the charge transferred in one current pulse of the PCR unit was calculated.

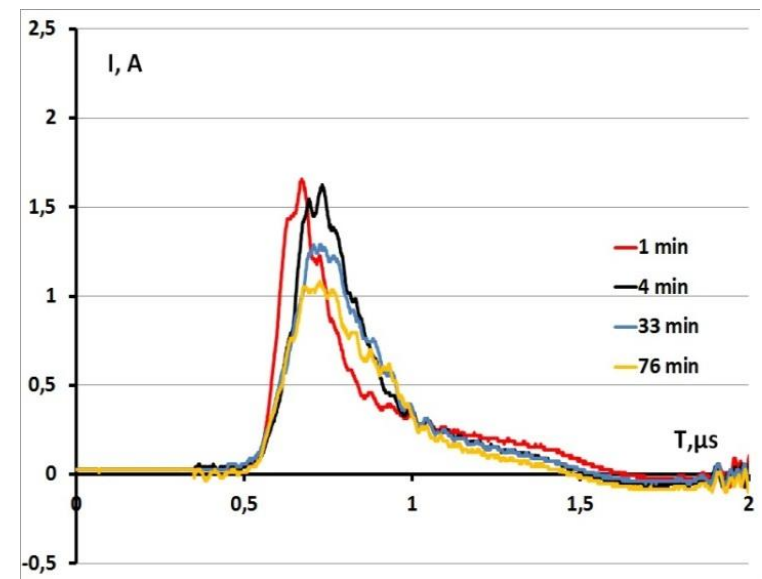

Fig. 7. Oscillograms of the discharge current pulses, PCR with stainless steel cathodes at the maximum load and $H V$ pulse energy of $9.657 \mathrm{~mJ}$ recorded at different operation duration 


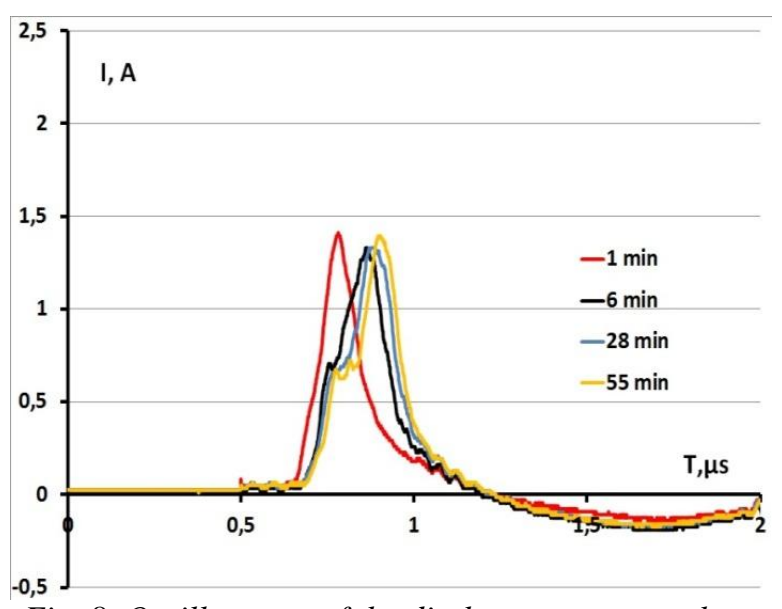

Fig. 8. Oscillograms of the discharge current pulses, PCR with copper cathodes at the partial load and $H V$ pulse energy of $7.775 \mathrm{~mJ}$ recorded at different operation duration

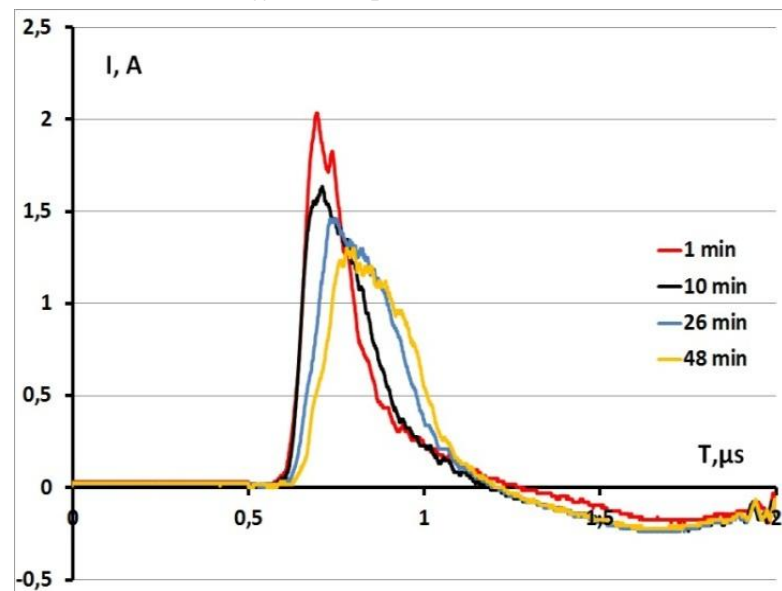

Fig. 9. Oscillograms of the discharge current pulses, PCR with copper cathodes at the maximum load and $H V$ pulse energy of $9.482 \mathrm{~mJ}$ recorded at different operation duration

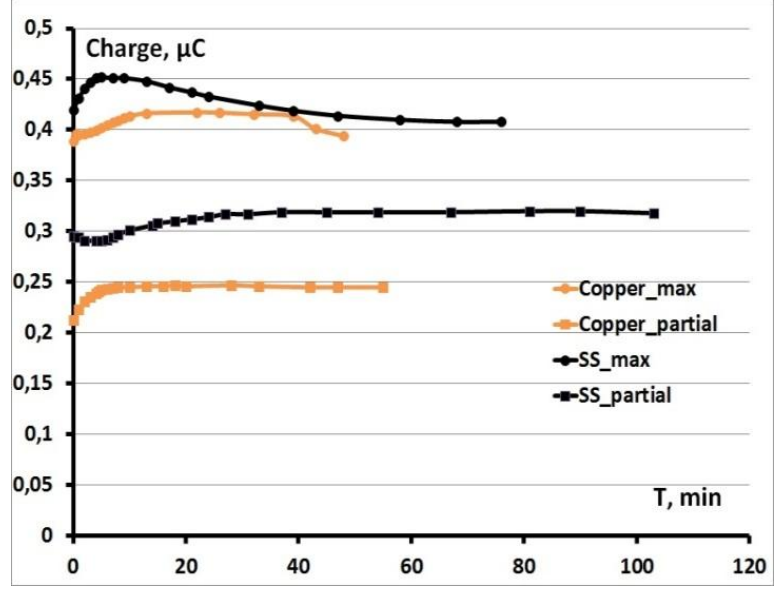

Fig. 10. Charge transferred in the discharge current pulse of the PCR with stainless steel and copper cathodes at the maximum and partial power depending on the duration of operation

In Fig. 10, the dependence of the charge value transferred in the discharge current pulse for the PCR with stainless steel and copper cathodes at the partial and maximum loads is shown. At the partial load, in the first minutes of PCR operation, there is a tendency to increase the charge in the current pulse. After a certain time, the amount of charge transferred in the current pulse is stabilized. At the maximum load, both for stainless steel and copper cathodes, the increase in the pulse charge is replaced by its decrease. For copper cathodes, there is a long period of $\sim 26 \mathrm{~min}$, when the value of the transferred charge remains unchanged.

In Fig. 10, it is shown that the amount of charge transferred in the discharge current pulse for stainless steel cathodes is greater than for copper cathodes under all the modes of PCR operation. Under the partial load mode, this difference reaches $20 \%$, under the maximum load mode, the difference is noticeably lower than $\sim 5 \%$. This can serve as a confirmation that the temperature of corona surface for stainless steel cathodes is higher than that of copper cathodes.

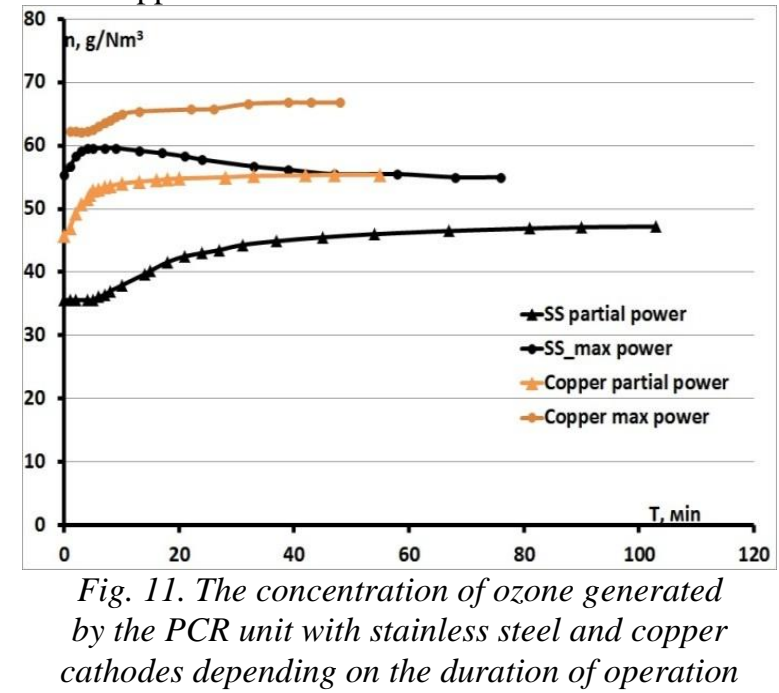

In Fig. 11, the dependence of ozone concentration at the outlet of the PCR unit on the duration of the PCR unit operation is shown. Comparing these curves with the curves shown in Fig. 10, it can be seen that the course of the curve showing the concentration dependence on the operating time practically repeats the corresponding dependence of the charge transferred in the current pulse, both for the PCR with stainless steel and copper cathodes.

The data presented in Fig. 11 show that ozone concentration generated by the PCR unit with copper cathodes is $25 \%$ higher than ozone concentration generated by the PCR with stainless steel cathodes under the partial and maximum loads. The energy efficiency of ozone synthesis for the PCR with stainless steel cathodes is $16.92 \mathrm{~W}$. and $14.7 \mathrm{~W} \cdot \mathrm{h} / \mathrm{gO}_{3}$ for the maximum and partial load modes, respectively. The energy efficiency of ozone synthesis for the PCR with copper cathodes is 13.62 and $8.925 \mathrm{~W} \cdot \mathrm{h} / \mathrm{gO}_{3}$ for the maximum and partial loads, respectively.

\section{DISCUSSION OF EXPERIMENTAL RESULTS}

The results obtained show significant differences in the characteristics of PCR operation with stainless steel and copper cathodes. Ozone production by the PCR unit with copper cathodes is about $20 \%$ higher both at the partial and maximum loads. At the maximum load for stainless steel cathodes, ozone concentration is decreased over time. Energy efficiency for both modes is 
approximately the same. This may show a significantly higher gas temperature for the corona surfaces of stainless steel cathodes. For the PCR with copper cathodes, the energy efficiency of ozone synthesis differs by $50 \%$ depending on the load mode, and at the maximum load mode it becomes similar to that of stainless steel. This may show that at the maximum load mode, the surface temperature of the copper cathode becomes similar to the surface temperature of the stainless steel cathode. The direction of the curves for the dependences of ozone concentration on time almost completely repeats the dependences for the amount of charge transferred in the discharge current pulse on time, with the exception of the final section for copper cathodes at the maximum load.

In the first minutes of operation, the pulse current is rapidly increased, which is apparently associated with gas heating at the cathode surface. At the partial load, the growth is stabilized for copper cathodes much earlier than for stainless steel cathodes. This can be caused by lower temperature of copper cathodes. An interesting feature of the maximum load mode is the decrease in the pulse current over time. As can be seen from the dependence for the pulse current of copper cathodes, this is a threshold effect, since it starts after 40 minutes of PCR operation and is clearly visible. For stainless steel cathodes, the conditions for the decrease in the pulse current are formed in the first minutes of operation, so the initial increase in the pulse current is directly replaced by a smooth decrease. In general case, heating should lead to the increase in the current, since the gas density is decreased during heating, and the value of the reduced electric field is increased respectively, making the discharge processes more intense. The threshold nature of the effect shows that a new mechanism changing the discharge pattern is activated. For stainless steel cathodes, this threshold is reached much earlier than for copper cathodes. It can be assumed that this is due to the peculiarity of the PCR power supply. In this experiment, the HV pulsed power supply is a sequence of HV pulses with the amplitude of $\sim 10 \mathrm{kV}$ against bias voltage, which is $\sim 500 \mathrm{~V}$. The bias power supply voltage is used to remove the volume charge accumulated during the discharge current pulse from the discharge gap. This makes it possible to significantly increase the operating frequency in comparison with the $\mathrm{HV}$ pulsed power supply only. Under the normal conditions, this voltage is insufficient to maintain a self-sustained gas discharge. A possible explanation for the decrease in the pulse current over time is that the cathode heating in a thin layer becomes such that the magnitude of the reduced electric field, during the time between HV pulses, becomes sufficient to maintain the gas-discharge processes at a certain low-intensity level. Thus, the bias voltage, on the one hand, helps to remove the space charge formed during the current pulse from the discharge gap, and on the other hand, it itself becomes the cause for the emergence of new one. The negative space charge generated during the time between the $\mathrm{HV}$ pulses is present in the discharge gap at the time of the next voltage pulse and screens the electric field generated at the cathode during the HV pulse. This leads to the decrease in the pulse current, and may lead to the gas discharge transition into a spark. For stainless steel cathodes, the heating of corona surface to a threshold level occurs rather quickly due to a low thermal conductivity of stainless steel. The fact that copper cathodes are heated to a threshold level is explained by the fact that the structural element of the PCR on which the cathode sections are located is made of stainless steel; during operation, it is heated from the copper cathode sections, and the heat flux from the corona surface to the structural elements is gradually decreased. As a result, the surface temperature of copper cathode is increased, and the same happens for stainless steel cathodes. In case of copper cathodes, this effect can be eliminated by cooling the structural elements. In case of stainless steel cathodes, cooling of the structural elements does not make sense since the drop in the pulse current is due to the low heat dissipation of the cathode material itself.

\section{CONCLUSIONS}

In the paper, the differences in the parameters of the pulsed corona in oxygen for stainless steel and copper cathodes are shown. The amount of charge carried in one discharge current pulse for stainless steel cathodes at the partial load is $15 \%$ higher than for copper cathodes at the same voltage pulse amplitude. This serves as an indirect confirmation of the higher value for the reduced electric field $\mathrm{E} / \mathrm{N}$ in the generation zone, as a result of the increased temperature. Ozone production efficiency of the stainless steel electrode system is less than $25 \%$ in comparison with copper cathodes at the maximum load, and $60 \%$ at the partial load. This may also be due to the increased temperature of corona surface for the cathode. The results obtained show that for more efficient ozone synthesis, in addition to using cathodes made of materials with higher specific thermal conductivity, forced cooling of the entire cathode system is also required.

\section{REFERENCES}

1. V.I. Golota, G.V. Taran, AA. Zamuriev. Development of ozone-dynamic technology for processing used tyres // Problems of Atomic Science and Technology. Series "Plasma Electronics and New Methods of Acceleration”. 2015, № 4(98), p. 310-314.

2. V.I. Golota, G.V. Taran, A.A. Zamuriev, P.O. Opalev, D.V. Kudin. Improvement of ozonedynamic methodfor used tire recycling // Ecology and Industry. 2017, № 1 (50), p. 94-99.

3. L.F. Dolina. New methods and equipment for the disinfection of waste water and natural waters. Dnepropetrovsk: "Continent", 2003, 218 p. ISBN-9967086-29-2.

4. O.V. Bolotov, V.I. Golota, Y.V. Sitnikova. Measurement of rotational temperature of molecular nitrogen in the anode area of negative corona in air under trichel pulse mode // Problems of Atomic Science and Technology. 2018, № 4, p. 200-203.

Article received 06.10.2021 


\section{ВЛИЯНИЕ МАТЕРИАЛА КАТОДА НА ХАРАКТЕРИСТИКИ ИМПУЛЬСНОЙ ОТРИЦАТЕЛЬНОЙ КОРОНЫ В КИСЛОРОДЕ}

\section{В.И. Голота, Б.Б. Кадолин, Г.В. Таран, И.А. Паценко}

Исследовано изменение во времени формы импульсов разрядного тока импульсной отрицательной короны в кислороде с медными катодами и катодами из нержавеющей стали для двух режимов горения разряда, заключающееся в уменьшении амплитуды импульса и увеличении их длительности на полувысоте. Показано, что для катодов из нержавеющей стали количество электрического заряда, переносимого в одном импульсе разрядного тока, на 15\% больше чем для медных катодов. Также показано, что в режиме максимальной нагрузки величина заряда, переносимого в одном импульсе разрядного тока, со временем уменьшается на $10 \%$ для обоих типов катодов. Показано, что в электродной системе с катодами из меди наработка озона происходит на 25\% более эффективно.

\section{ВПЛИВ МАТЕРІАЛУ КАТОДА НА ХАРАКТЕРИСТИКИ ІМПУЛЬСНОЇ НЕГАТИВНОЇ КОРОНИ В КИСНІ}

\section{В.І. Голота, Б.Б. Кадолін, Г.В. Таран, І.А. Пащенко}

Досліджено зміну в часі форми імпульсів розрядного струму імпульсної негативної корони в кисні $з$ мідними катодами і катодами 3 нержавіючої сталі для двох режимів горіння розряду, що полягає в зменшенні амплітуди імпульсу і збільшенні їх тривалості на напіввисоті. Показано, що для катодів 3 нержавіючої сталі кількість електричного заряду, що переноситься в одному імпульсі розрядного струму, на $15 \%$ більше ніж для мідних катодів. Також показано, що в режимі максимального навантаження величина заряду, що переноситься в одному імпульсі розрядного струму з часом зменшується на $10 \%$ для обох типів катодів. Показано, що в електродній системі з катодами з міді напрацювання озону відбувається на 25\% ефективніше. 